Article

\title{
Two Novel Polysaccharides in Psoralea corylifolia L and anti-A549 Lung Cancer Cells Activity In Vitro
}

\author{
Zhenhua Yin ${ }^{1,2,+}\left(\mathbb{D}\right.$, Wei Zhang ${ }^{2,+}$, Juanjuan Zhang ${ }^{1,2}$, Huili Liu ${ }^{1}$, Qingfeng Guo ${ }^{1,2}{ }^{(\mathbb{D}}$, \\ Lin Chen ${ }^{1,2}$, Jinmei Wang ${ }^{3, *}$ and Wenyi Kang $2,3, * \mathbb{D}$ \\ 1 Henan Joint International Research Laboratory of Drug Discovery of Small Molecules, \\ Zhengzhou 450063, China; yinzhenhua1000@126.com (Z.Y.); zhangjuan8908@163.com (J.Z.); \\ huililiu@infm.hhstu.edu.cn (H.L.); guoqf.2008@163.com (Q.G.); lchenchina@163.com (L.C.) \\ 2 Zhengzhou Key Laboratory of Medicinal Resources Research, Huanghe Science and Technology College, \\ Zhengzhou 450063, China; zzzwwwqq@126.com \\ 3 National R \& D Center for Edible Fungus Processing Technology, Henan University, Kaifeng 475004, China \\ * Correspondence: wangjinmeiscp@126.com (J.W.); kangweny@hotmail.com (W.K.) \\ + These authors contributed equally to this work.
}

Received: 10 September 2019; Accepted: 14 October 2019; Published: 16 October 2019

\begin{abstract}
Two novel water soluble heteroglycan (PCp-I and PCp-II) with anti-A549 lung cancer cells activity were isolated from Psoralea corylifolia $\mathrm{L}$. Their average molecular weights were $2.721 \times 10^{4}$ and $2.850 \times 10^{4}$. PCp-I and PCp-II had the same monosaccharide composition, but their molar ratios were different. Based on methylation and NMR spectroscopy, the part structure of PCp-I was identified. The results of scanning electron microscope (SEM) showed that PCp-I had an irregular porous structure and PCp-II was flaky and irregularly curved. The results of thermogravimetry-differential scanning calorimetry (TG-DSC) showed that PCp-I and PCp-II had good thermal stability. Furthermore, PCp-I and PCp-II exhibited significant anti-A549 lung cancer cells activity $\left(\mathrm{IC}_{50}=64.84\right.$ and $\left.126.30 \mu \mathrm{M}\right)$ in vitro.
\end{abstract}

Keywords: Psoralea corylifolia L; polysaccharides; structure; antitumor activity

\section{Introduction}

Polysaccharides, as an important carbohydrate in nature, are from different sources, such as plant, fungi, and algae, and they exhibit different chemical and biological activities, depending on the structure and nature of the monosaccharides [1]. Due to the physicochemical and functional properties of polysaccharides, i.e., their water retention ability, filming capacity, antioxidant, anti-microbial, immunomodulatory, anti-cancer, constipation, and antithrombus activities [2-7], polysaccharides are used in a wide variety of industrial applications, such as food, pharmaceuticals, and textiles. However, inrecent years, due to its high molecular weight, polysaccharides have poor water solubility, so there has been increasing interest in water-soluble polysaccharides as an important class of bioactive substances that may compete with traditional polysaccharides due to their potential biological activities and processing properties.

Psoralea corylifolia L. (PC), belonging to Leguminosae, is one of the most popular traditional Chinese medicines used for psoriasis and vitiligo [8,9]. Phytochemical researches show that $P$. corylifolia contains coumarins, flavonoids, and monoterpene phenols $[10,11]$. As for the polysaccharides of $P$. corylifolia, the studies on polysaccharides from $P$. corylifolia purification and their structural characteristics and biological activities for $P$. corylifolia polysaccharides were few, and only a few scholars have conducted preliminary studies, for example Zheng C X et al. [12] initially studied the feasibility and the mechanism of the polysaccharide from $P$. corylifolia for the repair of articular cartilage defects in rabbits. Yang G and 
Li F S et al. $[13,14]$ initially studied the immunomodulatory activities on normol mice of P. corylifolia fructus. crude polysaccharide, but the potential active components have not been identified. Recent studies suggested that extracts from P. corylifolia could inhibit the growth of ehrlich ascites tumor and lung cancer cells $[15,16]$. However, there is relatively little information pertaining to the purification and their structural characteristics and biological activities of water-soluble polysaccharides that were isolated from P. corylifolia.

At present, some scholars have found that the structure of polysaccharides is closely related to its biological activity $[17,18]$. Clarifying the structures of polysaccharides is an interesting goal to understand structure-activity relationships and causes of these biological activities. Therefore, in this study, polysaccharides of $P$. corylifolia were isolated by DEAE-52 cellulose column chromatography and Sephadex G-100 chromatography. The structures were identified by the methods of fourier transform-infrared spectroscopy (FT-IR), nuclear magnetic resonance (NMR), gas chromatography-mass (GC-MS), and scanning electron microscope (SEM). Furthermore, the antitumor activity towards anti-A549 lung cancer cells was assayed, aiming to provide fundamental information on the structure characterization and reveal the anti-A549 lung cancer cells activity, which provided theoretical basis for further research.

\section{Results and Discussion}

\subsection{Isolation and Purification of Polysaccharides}

The refined polysaccharide ( $80 \mathrm{~g}$, yield of $1.82 \%$ ) was fractionated by DEAE- 52 cellulose column chromatography, eluted stepwise with ultra-pure water and different concentrations of aqueous sodium chloride, respectively, and ultra-pure water eluate was pooled as PC-I (yield of $18.04 \%$ ), $0.1 \mathrm{~mol} / \mathrm{L} \mathrm{NaCl}$ eluate was pooled as PC-II (yield of 5.32\%). Figure 1 showed the procedure. They were further purified by gel chromatography on a Sephadex G-100 column and PCp-I and PCp-II were obtained with yields of $39.71 \%$ and $36.80 \%$, respectively (Figure 2). PCp-I was neutral polysaccharides that were eluted with water. PCp-II was acidic polysaccharides eluted with $0.1 \mathrm{~mol} / \mathrm{L} \mathrm{NaCl}$ through anion-exchange chromatography [19].

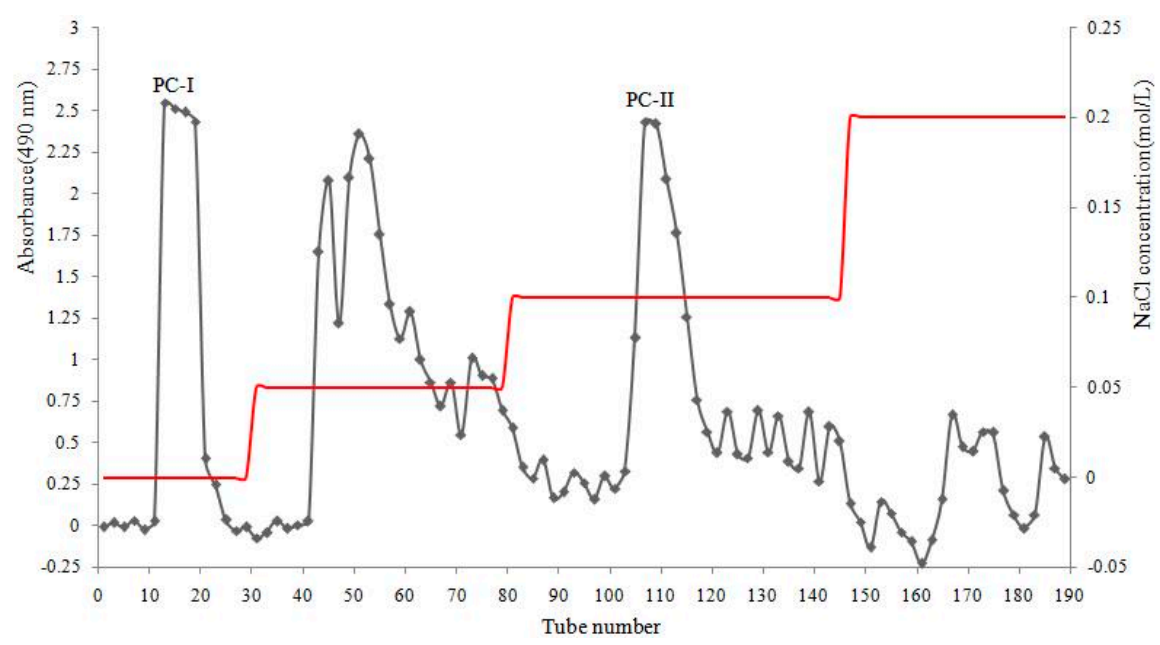

Figure 1. DEAE-52 chromatography of crude polysaccharide from P. corylifolia. 

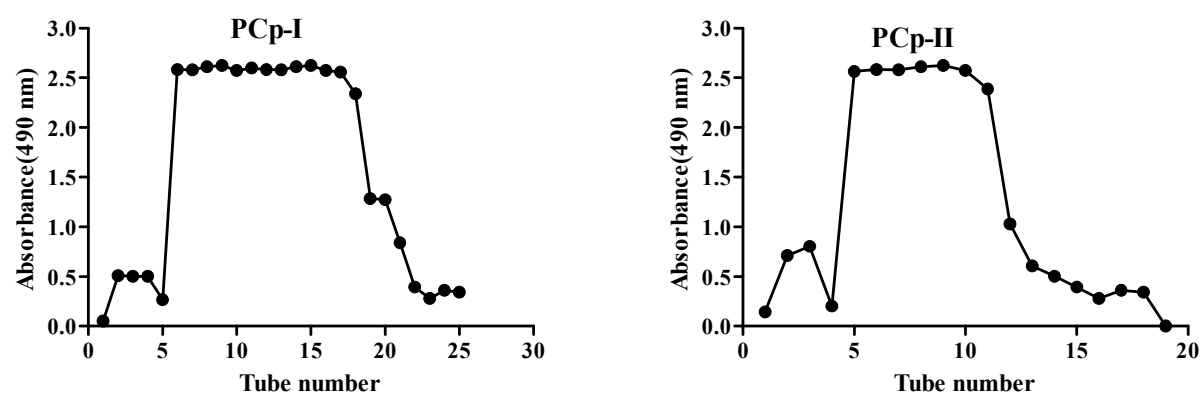

Figure 2. Sephadex G-100 chromatography of PC-I and PC-II.

\subsection{General Physicochemical Properties}

Table 1 showed the general physicochemical properties of PCp-I and PCp-II. The total sugar contents of PCp-I and PCp-II were $96.35 \pm 0.42 \%$ and $97.07 \pm 0.34 \%$, respectively, the protein content were $0.082 \pm 0.002 \%$ and $0.077 \pm 0.001 \%$, respectively, which showed that PCp-I and PCp-II had high purity and little protein. PCp-I and PCp-II were white powder, soluble in water, and insoluble in ethanol, $n$-butanol, acetone, chloroform, and petroleum ether. Fehling reagent reaction and ferric chloride reaction were negative, which indicated that the two polysaccharides did not contain free monosaccharide and polyphenols, and the reaction of the two polysaccharides with I-KI reaction was also negative, indicating that the two polysaccharides were not starch polysaccharides.

Table 1. The general physicochemical properties of PCp-I and PCp-II.

\begin{tabular}{ccc}
\hline Physicochemical Properties & PCp-I & PCp-II \\
\hline Appearance & Straw yellow and fluffy & Straw yellow and fluffy \\
Solubility & & \\
Hot water & Soluble & Soluble \\
Cold water & Soluble & Soluble \\
Ethanol, & Insoluble & Insoluble \\
$n$-Butanol & Insoluble & Insoluble \\
Acetone & Insoluble & Insoluble \\
Chloroform & Insoluble & Insoluble \\
Petroleum ether & Insoluble & Insoluble \\
Chemical Reaction & & \\
Coomassie brilliant blue staining & + & + \\
Fehling reagent & - & - \\
Ferric chloride & - & - \\
I-KI & - & - \\
\hline
\end{tabular}

\subsection{Molecular Weight and Monosaccharide Composition Analysis}

The homogeneity and molecular weight of PCp-I and PCp-II were determined using high performance size-exclusion chromatography (HPSEC), and only a single peak was observed (Figure 3 and Table 2). The molecular weight was estimated to be approximately $2.721 \times 10^{4}$ and $2.850 \times 10^{4} \mathrm{~g} / \mathrm{mol}$, according to a standard calibration curve that was obtained from definite molecular weight dextrans. The Mn was $1.911 \times 10^{4}$ and $2.339 \times 10^{4} \mathrm{~g} / \mathrm{mol}$, respectively. The dispersion coefficient $(\mathrm{Mw} / \mathrm{Mn})$ was used to be a judgment as to whether the molecular weight was distributed uniformly or not. 


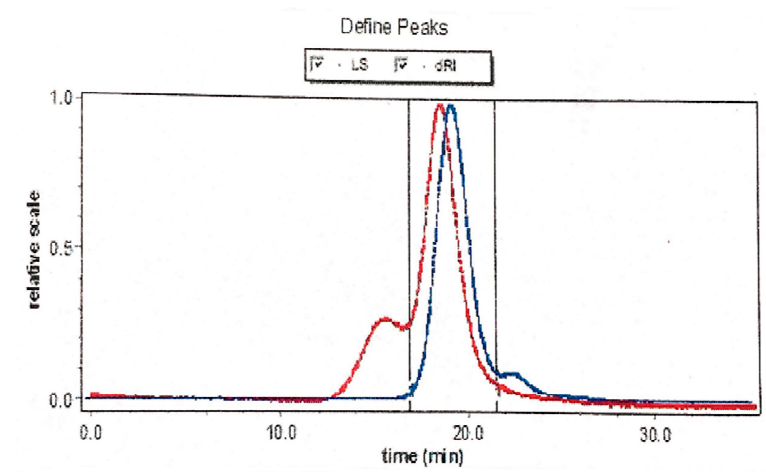

(a)

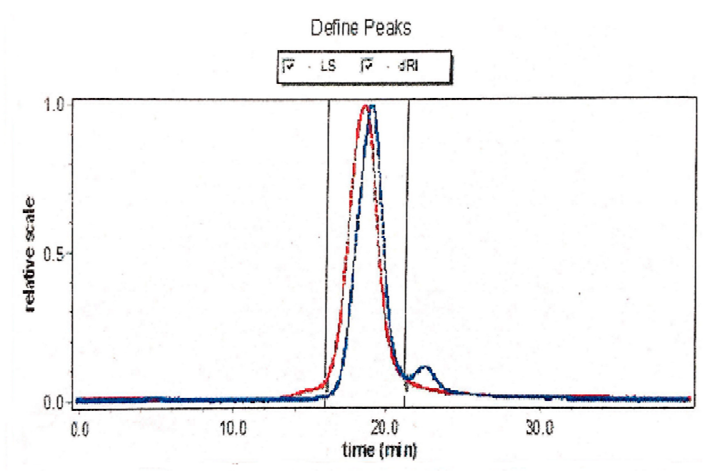

(b)

Figure 3. performance size-exclusion chromatography (HPSEC) elution profiles of PCp-I (a) and PCp-II (b).

Table 2. Molecular weight of PCp-1 and PCp-4.

\begin{tabular}{cccc}
\hline \multirow{2}{*}{ Samples } & \multicolumn{2}{c}{ Molecular Weight $(\mathrm{g} / \mathbf{m o l})$} & \multirow{2}{*}{ Mw/Mn } \\
\cline { 2 - 3 } & $\mathbf{M w}$ & $\mathbf{M n}$ & \\
\hline PCp-I & $2.721 \times 10^{4}$ & $1.911 \times 10^{4}$ & 1.424 \\
PCp-II & $2.850 \times 10^{4}$ & $2.339 \times 10^{4}$ & 1.219 \\
\hline
\end{tabular}

Gas Chromatography (GC) [20] and High-Performance Liquid Chromatography (HPLC) [21] were more commonly used to determine the monosaccharide composition. GC was the method for neutral sugar analysis with superb resolution and high sensitivity, however it required derivatization prior to analysis and it could not directly detect acid sugar [22]. Usually, GC analysis could give the accurate content of sugars in the polysaccharides. In our study, PCp-I and PCp-II were first hydrolyzed and acetylated, and then the monosaccharide compositions were measured by GC and identified by comparing the retention time of standards. In Table 3, PCp-I had a high amount of galactose and arabinose, and PCp-II mainly consisted of rhamnose, xylose, and galactose.

Table 3. Monosaccharide compositions of PCp-Iand PCp-II.

\begin{tabular}{ccccccc}
\hline \multirow{2}{*}{ Polysaccharide } & \multicolumn{7}{c}{ Major Monosaccharide Composition (Molar Ratio) } \\
\cline { 2 - 7 } & Rhamnose & Arabinose & Xylose & Mannose & Glucose & Galactose \\
\hline PCp-I & 1.65 & 4.47 & 2 & 2.06 & 0.946 & 24.76 \\
PCp-II & 2.79 & 1.97 & 7.52 & 0.283 & 0.187 & 6.62 \\
\hline
\end{tabular}

\subsection{FT-IR Spectra Analysis}

FT-IR spectroscopy was used to examine the main functional groups of carbohydrates [23]. Figure 4 showed the FT-IR spectra of PCp-I and PCp-II. In the FT-IR spectrum, a strong and broad band at 3386 and $3416 \mathrm{~cm}^{-1}$ were the characteristic of $\mathrm{O}-\mathrm{H}$ stretching frequency, which was indicative of the strong inter- and intra-molecular interactions of the polysaccharide chains [24]. The peaks at 2934 and $2937 \mathrm{~cm}^{-1}$ were assigned to aliphatic C-H stretching [25]. The absorption peaks around 1610, 1417, and $1070 \mathrm{~cm}^{-1}$ were assigned to bending vibration of $\mathrm{C}-\mathrm{OH}$ and $\mathrm{C}-\mathrm{O}$ stretching of ether and anti-symmetric stretching band of $\mathrm{C}-\mathrm{O}-\mathrm{C}$ groups, respectively [26]. The $\alpha$ and $\beta$ conformations of the carbohydrate could be determined by the peak position of the terminal carbon in the $950-750 \mathrm{~cm}^{-1}$ region, where $870-840 \mathrm{~cm}^{-1}$ correspond to $\alpha$ configuration and $\beta$ configuration belong to $890 \mathrm{~cm}^{-1}$. The peaks that were observed at 896 and $893 \mathrm{~cm}^{-1}$ indicated that the PCp-I and PCp-II had a $\beta$-glycoside link [27]. 

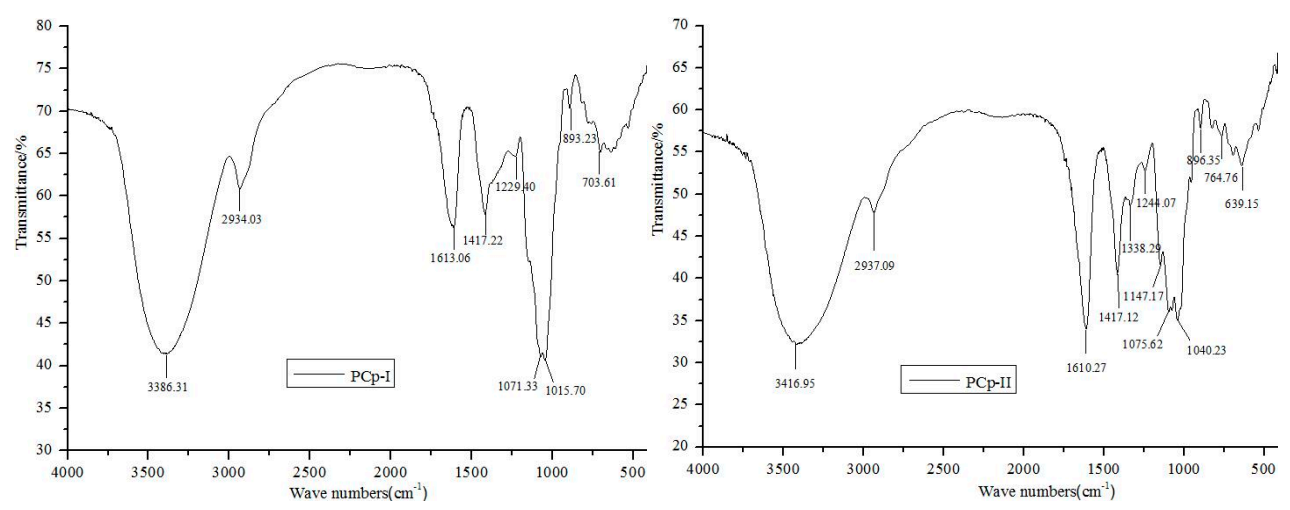

Figure 4. Fourier transform-infrared spectroscopy (FT-IR) spectra of PCp-I and PCp-II.

\subsection{Methylation Analysis}

The linkage patterns of PCp-I and the corresponding percentages of alditol acetates were investigated while using methylation and GC-MS method. A major peak was observed in the GC profile (Data not shown), which was identified as 2,3,6-Tri-O-Me-Gal (35.66\%), indicating that the main sugar residue of 1,4-linked-Gal $p$ was present in PCp-I. The total percentage of terminal sugar residues $(2.34 \%$ of T-Glcp and $6.74 \%$ of T-Galp) was $9.08 \%$. The sugar residues of 1,3 -linked-Gal $p$ (3.80\%), 1,5-linked-Araf (7.91\%), 1,3,6-linked-Manp (3.09) and 1,4-linked-Manp (2.18\%) were also detected (Table 4). In addition, the content of rhamnose was reduced and the xylose was not detected. These results indicated that the main sugar residues of PCP-I were galactose and arabinose. The ratio change might be due to the degradation of polysaccharide chain during the reduction procedure; however, the intrinsic reason still needs to be further discussed [22]. As a whole, the results of methylation were basically consistent with the monosaccharide composition analysis.

Table 4. Results of the main methylation analysis of PCp-I.

\begin{tabular}{ccc}
\hline Partially $\boldsymbol{O}$-Methylalditol Acetate & SF(\%) & Linkage Type \\
\hline 3-O-Me-Rha & 0.19 & $\rightarrow$ 2,4)-Rha $p-(1 \rightarrow$ \\
2,3-di-O-Me-Ara & 7.91 & $\rightarrow 5$-Araf $-(1 \rightarrow$ \\
2,4,6-Tri-O-Me-Gal & 3.80 & $\rightarrow 3)$-Gal $p$ - $(1 \rightarrow$ \\
2,3,4,6- tetra-O-Me-Gal & 6.74 & Galp- $(1 \rightarrow$ \\
2,3,6-Tri-O-Me-Gal & 35.66 & $\rightarrow 4)$-Galp- $(1 \rightarrow$ \\
2,3,4,6-tetra-O-Me-Glc & 2.34 & Glcp- $(1 \rightarrow$ \\
2,4-di-O-Me-Man & 3.09 & $\rightarrow 3,6)-M a n p-(1 \rightarrow$ \\
2,3,6-di-O-Me-Man & 2.18 & $\rightarrow 4)$-Manp- $(1 \rightarrow$ \\
\hline
\end{tabular}

Note: SF: \% of peak area of $O$-methyl alditol acetates relative to total area, determined by GC-MS. Sorting is not related to peak-out time.

\subsection{The Chemical Shifts Assignments of Different Linkage Patterns of PCP-I by NMR}

NMR spectroscopy, including one-dimensional (1D) and two-dimensional (2D) NMR spectra, was conducted for the elucidation of the structural features of PCp-I. The ${ }^{1} \mathrm{H}-\mathrm{NMR}$ spectrum (Figure $5 \mathrm{a}$ ) showed four signals in the anomeric region at $\delta 5.27(\mathrm{~A}), 5.10(\mathrm{~B}), 4.65(\mathrm{C})$, and $4.54(\mathrm{D})$. They were designated as $\mathrm{A}$ to $\mathrm{D}$ residues, according to their decreasing proton chemical shift values. In the ${ }^{13} \mathrm{C}-\mathrm{NMR}$ spectrum (Figure $5 \mathrm{~b}$ ) four anomeric signals appeared at $\delta 107.5,104.4,103.4$, and 98.5 . The other carbon signals were in the region $\delta 83.7-60.0$. The anomeric carbon chemical shift values of residues A to D were correlated to the anomeric proton signals of residues from the HSQC spectrum (Figure 5c).The anomeric carbon signal at $\delta 107.5$ correlated to anomeric proton signal of B $(\delta 5.10)$, $\delta 104.4$ correlated to the signals $\mathrm{C}(\delta 4.65)$, at 103.4 correlated to $\mathrm{D}(\delta 4.54)$, at $\delta 99.9$ correlated to $\mathrm{A}(\delta$ 5.27) residues, respectively. All of the ${ }^{1} \mathrm{H}$ and ${ }^{13} \mathrm{C}$ signals (Table 5) were assigned by ${ }^{1} \mathrm{H}-{ }^{13} \mathrm{C}$ HSQC (Figure $5 \mathrm{c}$ ) and ${ }^{1} \mathrm{H}-{ }^{1} \mathrm{H}$ COSY (Figure $5 \mathrm{~d}$ ) experiments. The signals around at (1.3 and $17 \mathrm{ppm}$ ) were 
assigned to the protons of the methyl group. The peaks in the HSQC (1.26, $17.17 \mathrm{ppm}$ ) (Figure 5c) indicated that PCp-I contained rhamnose residue.

Table 5. The ${ }^{1} \mathrm{H}-\mathrm{NMR}$ and ${ }^{13} \mathrm{C}-\mathrm{NMR}$ chemical shifts of PCp-I.

\begin{tabular}{ccccccc}
\hline \multirow{2}{*}{ Glucosyl Residue } & H-1/ & H-2/ & H-3/ & H-4/ & H-5/ & H-6(a,b)/ \\
\cline { 2 - 7 } & C-1 & C-2 & C-3 & C-4 & C-5 & C-6 \\
\hline A & 5.27 & 4.13 & 3.92 & 3.66 & 3.80 & 1.26 \\
$\rightarrow 2,4)-\alpha$-Rhap- $(1 \rightarrow$ & 98.5 & 77.7 & 71.9 & 84.2 & 72.1 & 17.2 \\
B & 5.04 & 4.15 & 3.96 & 4.23 & $3.88 / 3.92$ & - \\
$\rightarrow 5)-\alpha-$ Araf- $-(1 \rightarrow$ & 107.5 & 80.9 & 74.6 & 81.3 & 68.9 & - \\
C & 4.65 & 3.68 & 3.78 & 4.18 & 3.79 & $3.72 / 3.52$ \\
$\rightarrow 4)-\alpha-$ Galp- $(1 \rightarrow$ & 104.4 & 71.9 & 76.6 & 77.8 & 74.6 & 60.9 \\
D & 4.54 & 3.31 & 3.56 & 3.71 & 3.54 & $3.68 / 3.95$ \\
$\beta-G l c p-(1 \rightarrow$ & 103.4 & 69.7 & 76.0 & 71.8 & 75.8 & 60.8 \\
\hline
\end{tabular}

Residue A: In the ${ }^{1} \mathrm{H}$ spectrum, Residue A had an anomeric proton chemical shift at $\delta 5.27 \mathrm{ppm}$, with the low field anomeric signal showing that it was an $\alpha$-linked residue with relatively low content in PCp-I. It was identified as $\rightarrow 2,4)-\alpha$-Rhap- $\left(1 \rightarrow\right.$. The complete ${ }^{1} \mathrm{H}$ assignments were achieved through the COSY spectrum (Figure 5d), which were $\delta 4.13,3.92,3.66,3.80$, and $1.26 \mathrm{ppm}$ for H-2, H-3, H-4, $\mathrm{H}-5$, and H-6a/H6b, respectively (Table 5). The chemical shifts from $\mathrm{C}-1$ to $\mathrm{C}-5$ could be assigned from the ${ }^{1} \mathrm{H}-{ }^{13} \mathrm{C}$ HSQC spectrum, as shown in Table 5. All of the ${ }^{1} \mathrm{H}$ and ${ }^{13} \mathrm{C}$ chemical shifts that were assigned in this study (Table 5) were consistent with previous data [28], which corroborate the above assignments.

Residue B: Residue B had an anomeric proton signal at $\delta 5.04 \mathrm{ppm}$. The proton resonances (Table 5a) of residue B from H-1 to H-6 had been assigned to the $\alpha$-arabinofuranose residue [29]. The ${ }^{13} \mathrm{C}$ signal for the anomeric carbon was observed at $\delta 107.4 \mathrm{ppm}$. The carbon signals from C-2 to $C-5$ were identified from the HSQC spectrum as shown in Figure $5 c$ and Table 5 . The chemical shift of C-5 was decreased, which indicated that it was the value of methyl glycosides and residue B was (1,5)- $\alpha$-Araf $[30,31]$. All of the ${ }^{1} \mathrm{H}$ and ${ }^{13} \mathrm{C}$ chemical shifts assigned in this study (Table 5a). Residue B was assigned as $\rightarrow 5)$ - $\alpha$-Araf $-(1 \rightarrow$ by comparing with previous data [32] and the methylation analysis results.

Residue C: The signals of residue $\mathrm{E}$ at $\delta 4.65 \mathrm{ppm}$ and $104.4 \mathrm{ppm}$ corresponded to an $\beta$-linked residue with high content in PCp-I. This residue was tentatively assigned as $\beta$-1,4-linked-Galp by comparing with the reported data and peak intensity [33]. The proton and corresponding ${ }^{13} \mathrm{C}$ assignments of residue $\mathrm{C}$ were obtained from COSY and HSQC spectrums, as shown in Figure $5 \mathrm{c}, \mathrm{d}$ and Table 5. All of the ${ }^{1} \mathrm{H}$ and ${ }^{13} \mathrm{C}$ chemical shifts of residue $\mathrm{C}$ were inconsistent with the previous reports [28], and the corresponding intensity was supported by the methylation analysis results.

Residues D: Residue D was analyzed with the same way. The proton and carbon shifts of residue E were fully identified according to ${ }^{1} \mathrm{H}^{-1} \mathrm{H}$ COSY and HSQC spectras (Table 5). The results were compared with previous data and methylation analysis, residue $D$ was assigned as $\beta$-Glc $p-(1 \rightarrow[26,34]$. 


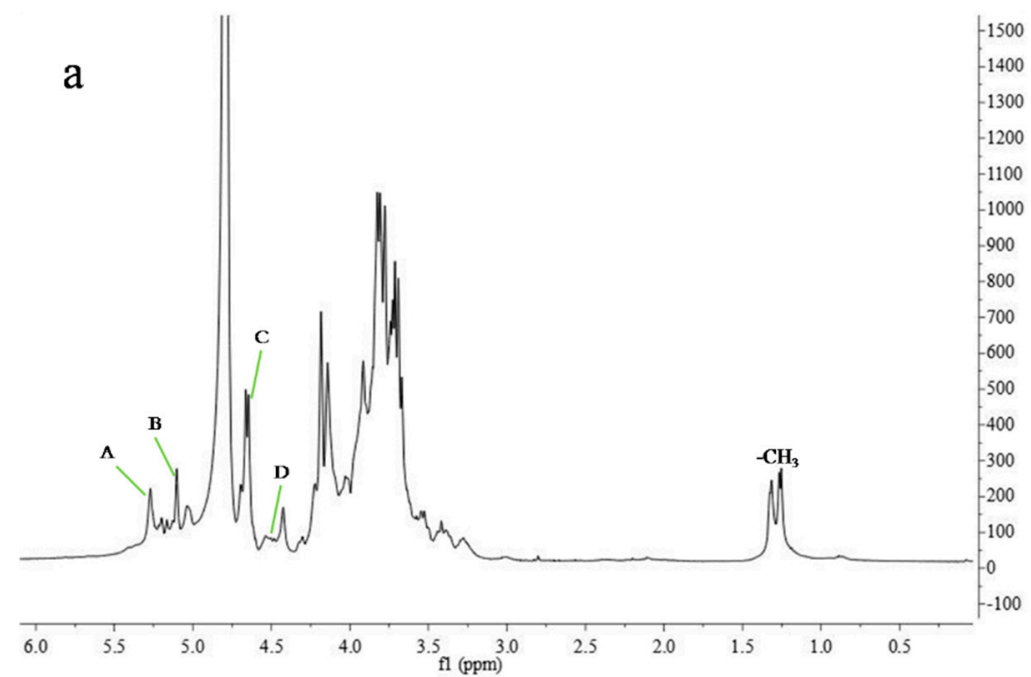

b
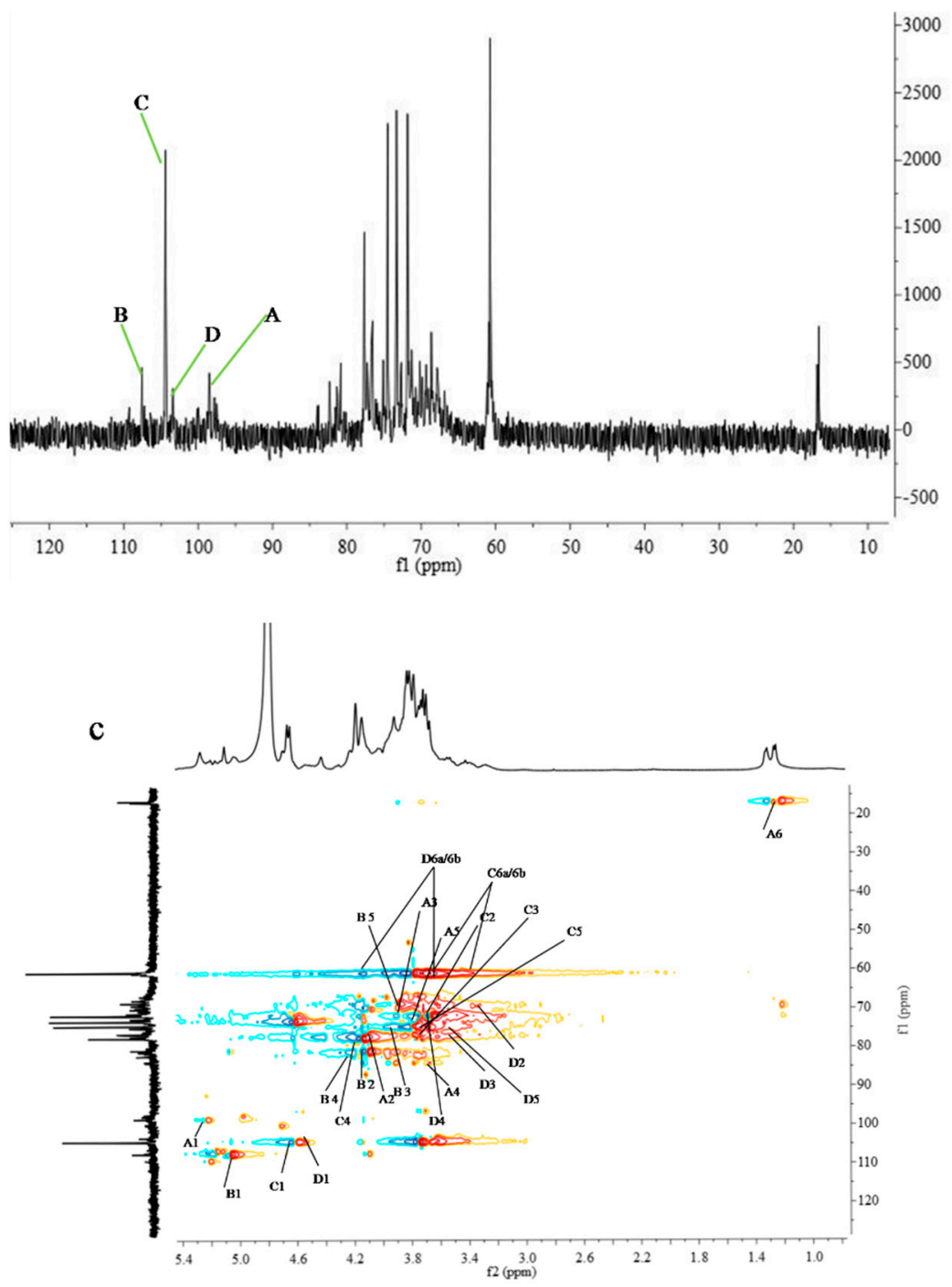

Figure 5. Cont. 


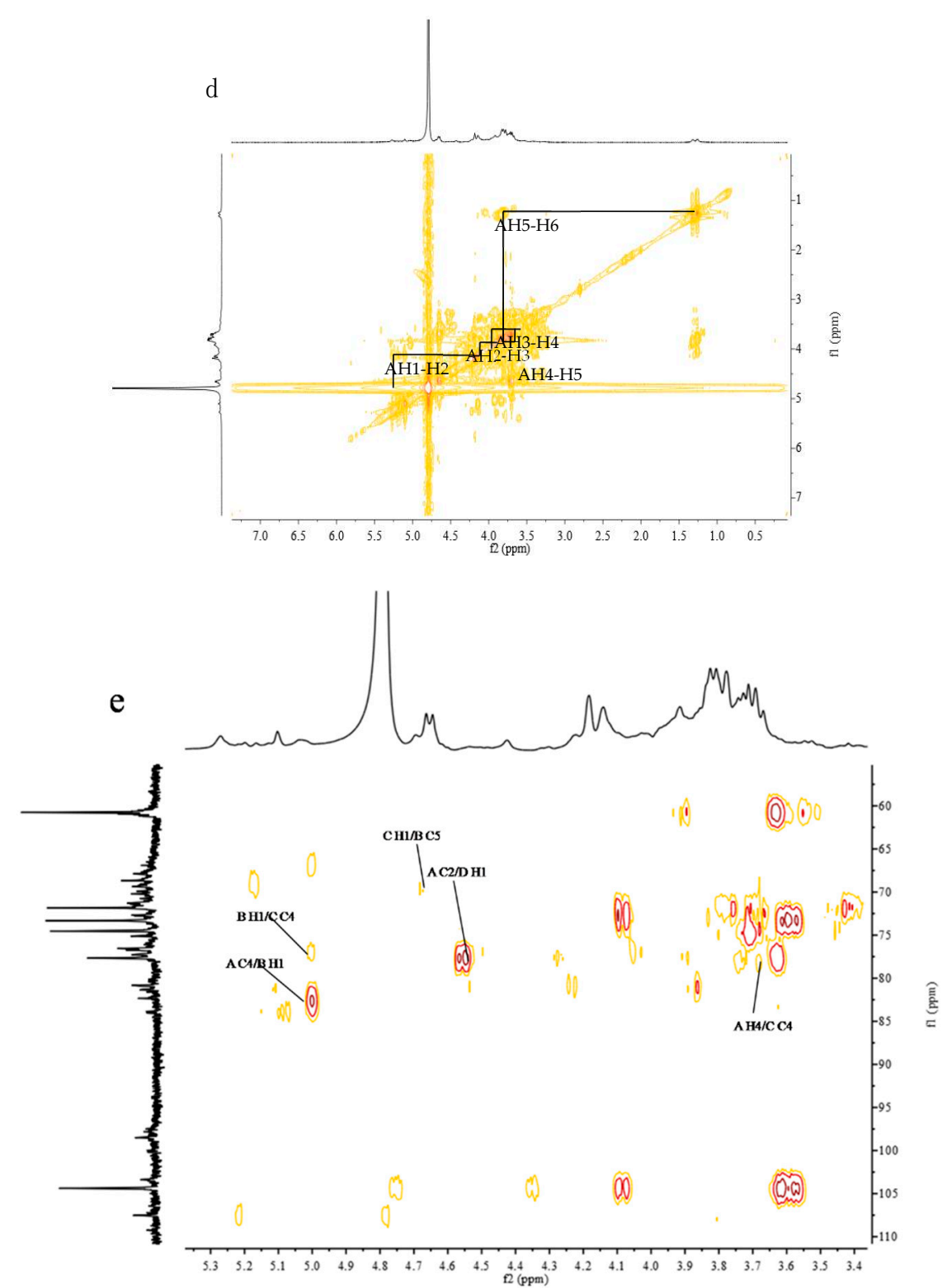

Figure 5. (a) ${ }^{1} \mathrm{H}-\mathrm{NMR}$ spectrum $\left(400 \mathrm{MHz}, \mathrm{D}_{2} \mathrm{O}, 30{ }^{\circ} \mathrm{C}\right)$; (b) ${ }^{13} \mathrm{C}$ NMR spectrum $\left(100 \mathrm{MHz}, . \mathrm{D}_{2} \mathrm{O}, 30{ }^{\circ} \mathrm{C}\right)$; (c) ${ }^{1} \mathrm{H} /{ }^{13} \mathrm{C}$ HSQC correlation spectrum; (d) ${ }^{1} \mathrm{H} /{ }^{1} \mathrm{H}$ COSY correlation spectrum of PCp-1; and, (e) ${ }^{1} \mathrm{H} /{ }^{13} \mathrm{C}$ HMBC correlation spectrum.

\subsection{Sequence Analysis of Polysaccharide Chain by HMBC Spectrum}

Once the ${ }^{1} \mathrm{H}$ and ${ }^{13} \mathrm{C}$ chemical shifts of sugar residues were completely assigned, the sequences of these residues were determined by observing residual connectivities in HMBC spectrum (Figure 6e and Table 6$)$. Cross peaks were found between $\mathrm{H}-4$ of residue $\mathrm{A}(\delta 3.66 \mathrm{ppm})$ and $\mathrm{C}-4$ of residue $\mathrm{C}$ $(\delta 77.8 \mathrm{ppm}), \mathrm{C}-2$ of residue $\mathrm{A}(\delta 77.7 \mathrm{ppm})$ and $\mathrm{H}-1$ of residue $\mathrm{D}(\delta 4.54 \mathrm{ppm})$, and $\mathrm{C}-4$ of residue $\mathrm{A}$ $(\delta 84.2 \mathrm{ppm})$ and $\mathrm{H}-1$ of residue $\mathrm{B}(\delta 5.04 \mathrm{ppm})$. The same way was used as those for residues of $\mathrm{B}, \mathrm{C}$, and D. Based on the monosaccharide composition, methylation and NMR spectroscopy, part structure of PCp-I was proposed. About some monosaccharide and methylation information were limited, so we cannot be inferred their location. 


$$
\begin{aligned}
\beta-G l c p-(1 \rightarrow \underset{\downarrow}{2,4)-\alpha-R h a p}-(1 \rightarrow & \\
4 & \text { 4)- } \alpha \text {-Gal } p-(1 \rightarrow 5)-\alpha-\operatorname{Ara} f-(1 \rightarrow 4)-\alpha-\operatorname{Gal} p-(1 \rightarrow 5)-\alpha-\operatorname{Ara} f-(1]_{\mathrm{n}}
\end{aligned}
$$

Table 6. The significant connectivities observed for the anomeric protons/carbons of PCp-1 in HMBC spectrum.

\begin{tabular}{ccccc}
\hline \multirow{2}{*}{ Sugar Residue } & H-1/C-1(ppm) & \multicolumn{3}{c}{ Connectivities } \\
\cline { 2 - 5 } & $\delta \mathbf{H} / \delta \mathbf{C}$ & $\delta \mathbf{H} / \delta \mathbf{C}$ & Residue & Atom \\
\hline \multirow{2}{*}{$\mathrm{A}$} & 3.66 & 77.8 & $\mathrm{C}$ & $\mathrm{C}-4$ \\
& 77.7 & 4.54 & $\mathrm{D}$ & $\mathrm{H}-1$ \\
& 84.2 & 5.04 & $\mathrm{~B}$ & $\mathrm{H}-1$ \\
\hline $\mathrm{B}$ & 5.04 & 77.8 & $\mathrm{C}$ & $\mathrm{C}-4$ \\
\hline \multirow{2}{*}{$\mathrm{C}$} & 4.65 & 68.9 & $\mathrm{~B}$ & $\mathrm{C}-5$ \\
& 77.8 & 3.88 & $\mathrm{~B}$ & $\mathrm{H}-5$ \\
\hline
\end{tabular}

\subsection{Molecular Morphology}

SEM imaged the two polysaccharides to better understand the molecular morphology of PCp-I and PCp-II. PCp-I had an irregular porous structure, as shown in Figure 6. The dense network structure was presented as a whole. PCp-II was flaky and irregularly curved, and the surface was smooth, there were very small gaps between the crystals, so that the polysaccharides were not completely assembled, which indicated that there were repulsive forces between the molecules of the polysaccharides [35].

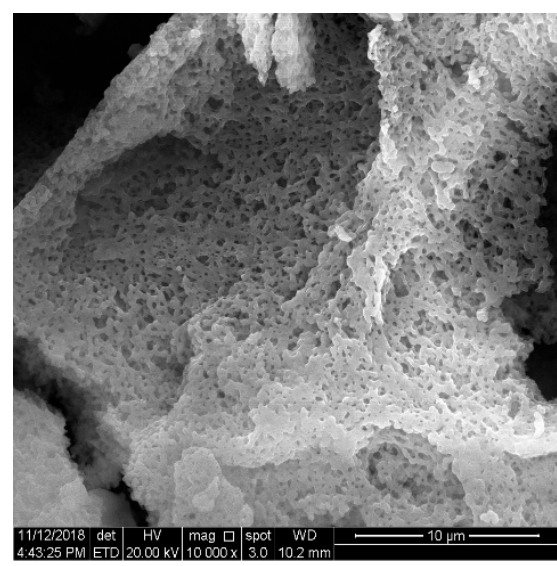

(a)

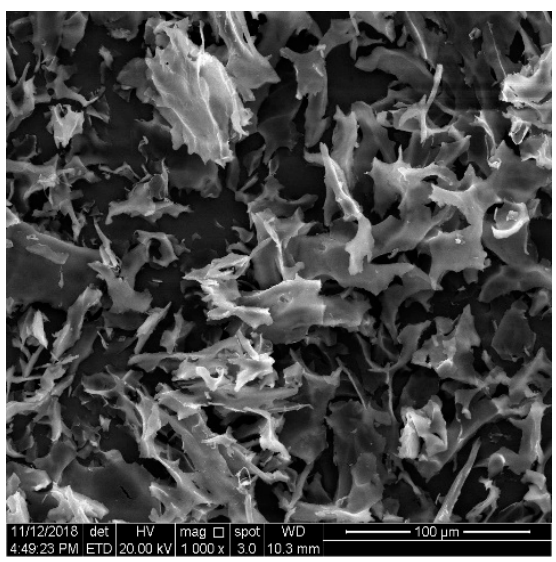

(b)

Figure 6. Photomicrographs of PCp-I (a) and PCp-II (b) as recorded by SEM.

\subsection{Thermal Stability Analysis}

Thermogravimetry (TG) and differential scanning calorimetry (DSC) measurements were used for studying the mass loss and thermal transitions in the course of heating under an inert atmosphere. Figure 7 and Table 7 illustrated the results. The TG experiments (Figure 7) showed two mass loss events for PCp-I and PCp-II, being the first near $100{ }^{\circ} \mathrm{C}$, which might be attributed to the loss of adsorbed and structural water of both polysaccharides, as related by other authors [36]. The DSC experiments showed, for both polysaccharides, an endothermic event near $100{ }^{\circ} \mathrm{C}$, absorbed heat were 98.10 and $236.80 \mathrm{~J} / \mathrm{g}$, probably due to the water evaporation, in agreement with TG analysis. The second mass loss event, with an onset temperature of 150.15 and $132.98^{\circ} \mathrm{C}$ and a peak temperature 
of 419.44 and $386.80{ }^{\circ} \mathrm{C}$ for PCp-I and PCp-II, respectively, resulted in a weight loss of $51.97 \%$ and $39.21 \%$, which might be attributed to the polysaccharide decomposition. The DSC experiments had good correlation with TG peak temperatures. The third mass loss event was a slow mass loss process, the decomposition process of both polysaccharides was basically over, and the final residual mass was $28.45 \%$ and $33.72 \%$, respectively. The DSC experiments showed that the thermal decomposition temperatures of PCp-I and PCp-II were $355.23{ }^{\circ} \mathrm{C}$ and $359.36^{\circ} \mathrm{C}$, which was significantly higher than that of other polysaccharides [37,38], and showed that PCp-I and PCp-II had good thermal stability.
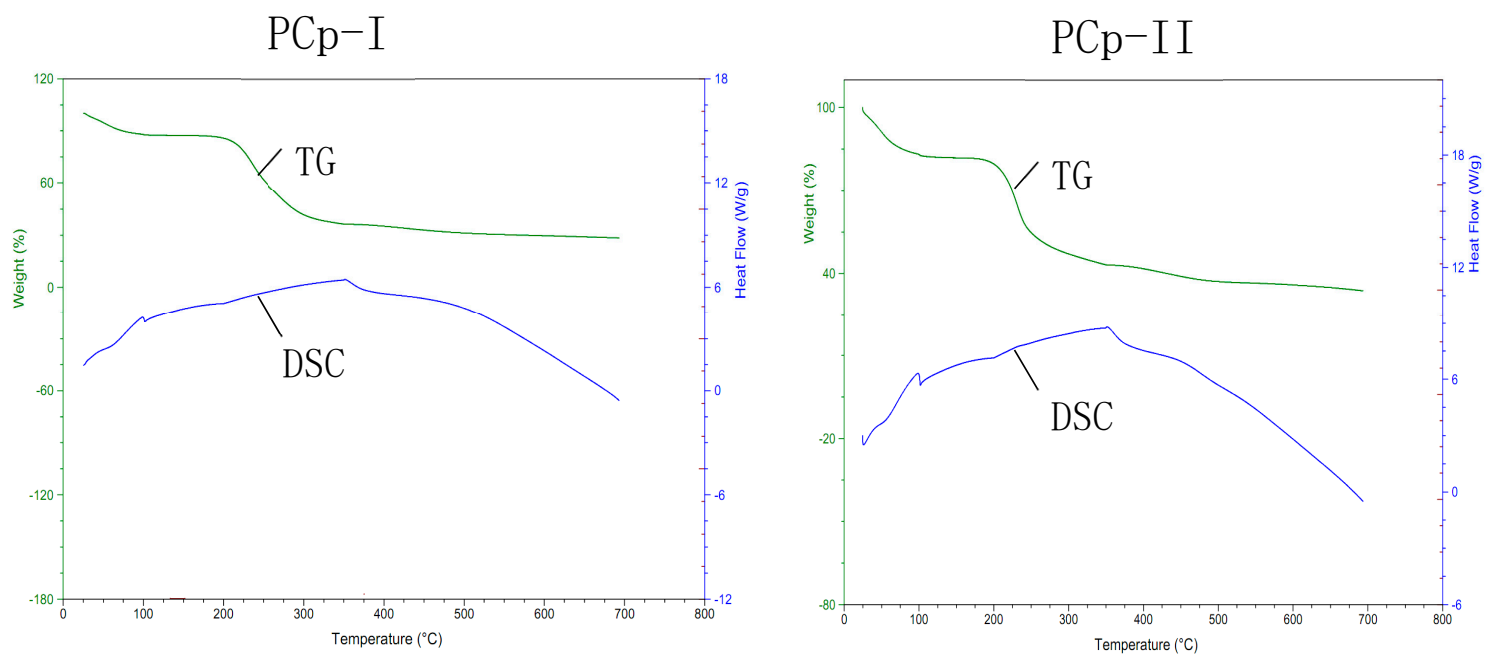

Figure 7. gravimetric and differential scanning calorimetric analysis of PCp-I and PCp-II.

Table 7. The thermal gravimetric and differential scanning calorimetric analysis results of PCp-I and PCp-II.

\begin{tabular}{|c|c|c|c|}
\hline \multicolumn{2}{|c|}{ DSC-TG Analytical Parameters } & PCp-I & PCp-II \\
\hline \multirow{3}{*}{ Phase I } & Began-end temperature $\left({ }^{\circ} \mathrm{C}\right)$ & 24.74 150.15 & $24.74 \sim 132.98$ \\
\hline & Enthalpy peak temperature $\left({ }^{\circ} \mathrm{C}\right)$ & $100.55(98.10 \mathrm{~J} / \mathrm{g})$ & $100.94(263.8 \mathrm{~J} / \mathrm{g})$ \\
\hline & Quality change (\%) & 10.34 & 15.05 \\
\hline \multirow{3}{*}{ Phase II } & Began-end temperature $\left({ }^{\circ} \mathrm{C}\right)$ & $150.15 \sim 419.44$ & $132.98 \sim 386.80$ \\
\hline & Enthalpy peak temperature $\left({ }^{\circ} \mathrm{C}\right)$ & 355.23 & 359.36 \\
\hline & Quality change (\%) & 51.97 & 39.21 \\
\hline \multirow{2}{*}{ Phase III } & Began-end temperature $\left({ }^{\circ} \mathrm{C}\right)$ & $419.44 \sim 693.75$ & $386.80 \sim 693.75$ \\
\hline & Quality change $(\%)$ & 8.75 & 8.18 \\
\hline 693.75 & Residual quality $\left({ }^{\circ} \mathrm{C}\right)$ & 28.45 & 33.72 \\
\hline
\end{tabular}

\subsection{PCp-I and PCp-II Inhibited the Proliferation of A549 Lung CancerCells}

In the course of tumor progression, cancer cells undergo a number of characteristic changes, including the growth-inhibitory signals or ability of proliferation independently of exogenous growth-promoting [39]. Significant tumor inhibition on A549 lung cancer cells was observed at different concentrations of PCp-I and PCp-II as compared with the control group (Figure 8). PCp-I and PCp-II could decrease A549 cell viability in a dose-dependent manner. At the concentration of $100 \mu \mathrm{M}$, the cell viabilities were $48.77 \%$ and $51.87 \%$, respectively. Comprehensive analysis, PCp-I and PCp-II had an inhibitory effect on A549 lung cancer cells ( $\mathrm{IC}_{50}=64.84$ and $126.30 \mu \mathrm{M}$ ), but their activities were lower than that of cisplatin as positive control $\left(\mathrm{IC}_{50}=11.00 \mu \mathrm{M}\right)$. Han et al [5] found that a water-soluble pectic polysaccharide HCA4S1 that isolated from Houttuynia cordata might inhibit the proliferation of A549 lung cancer cell by inducing cell cycle arrest and apoptosis, and the expression of cleaved caspase 3 and cyclinB1 was observed to be upregulated after the treatment with this polysaccharide. It was further found that PCp-I had structural fragments that were similar to that of HCA4S1. At present, Lentinan and Ginseng polysaccharide had anti-tumor activity and been 
used in clinical $[40,41]$. These suggest that $P$. corylifolia polysaccharides are of potential value in the treatment of lung cancer.
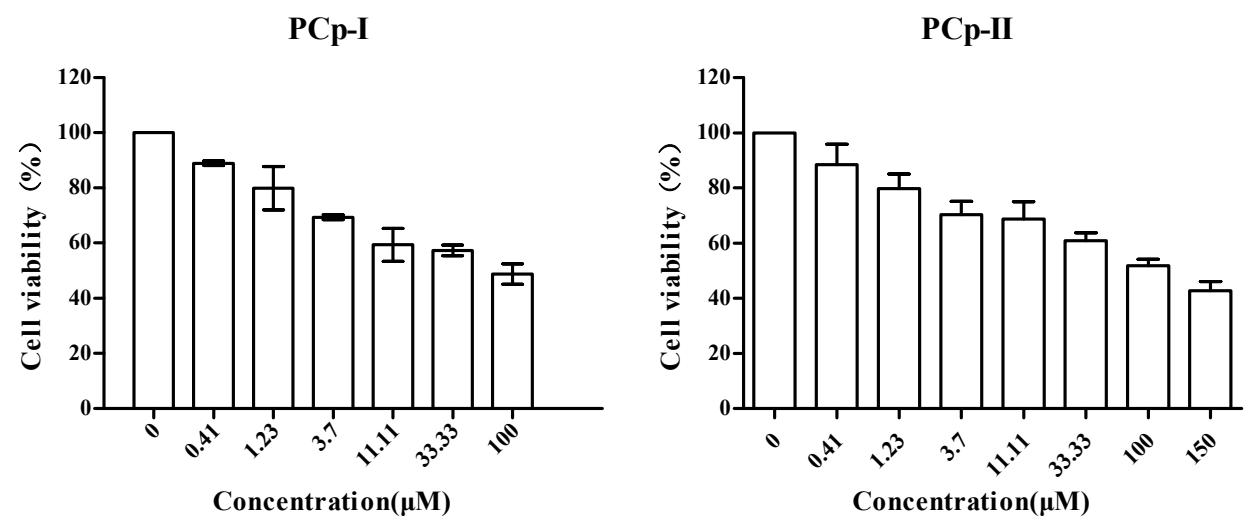

Figure 8. of PCp-I and PCp-II on cell viability of A549 lung cancer cells.

\section{Materials and Methods}

\subsection{Materials and Chemicals}

Psoralea corylifolia Linn. (PC) was purchased from Bozhou Yonggang Pieces Factory Co., Ltd. (Bozhou, China) which was identified by Changqin Li, the professor of pharmaceutical college of Henan University. The voucher specimens were deposited in the herbarium of Huanghe Science and Technology College.

The monosaccharides standard substances $(\mathrm{L}(+)$-rhamnose, $\mathrm{L}(+)$-arabinose, $\mathrm{D}(+)$-xylose, $\mathrm{D}(+)$-mannose, $\mathrm{D}(+)$-glucose, $\mathrm{D}$-galactose) were purchased from the $\mathrm{Dr}$ Ehrenstorfer $\mathrm{GmbH}$ (Germany). DEAE-52 Cellulose was purchased from Saipuruisi Technology Co., LTD. (Beijing, China). Sephadex G-100 was purchased from GE Healthcare Bio-Science AB (Stockholm, Sweden).

\subsection{Preparation of Polysaccharides Sample}

The extraction of polysaccharide from P. corylifolia (PC) was carried out according to our previous method [42], as demonstrated in Figure 9. The dried powder was successively soaked three times for $24 \mathrm{~h}$ each time with petroleum ether and $75 \%$ ethanol to eliminate some fat-soluble substances [43]. The soaked residue was extracted three times with ultra-pure water at $85{ }^{\circ} \mathrm{C}$. Three volumes of ethanol was added to the water extraction solution to precipitate the crude polysaccharide. The Sevage method [44] was used to remove proteins. The DEAE-52 cellulose column $(60 \mathrm{~cm} \times 2.5 \mathrm{~cm})$ and Sephadex G-100 column $(100 \mathrm{~cm} \times \Phi 1.5 \mathrm{~cm})$ chromatography were used to refine polysaccharide. 


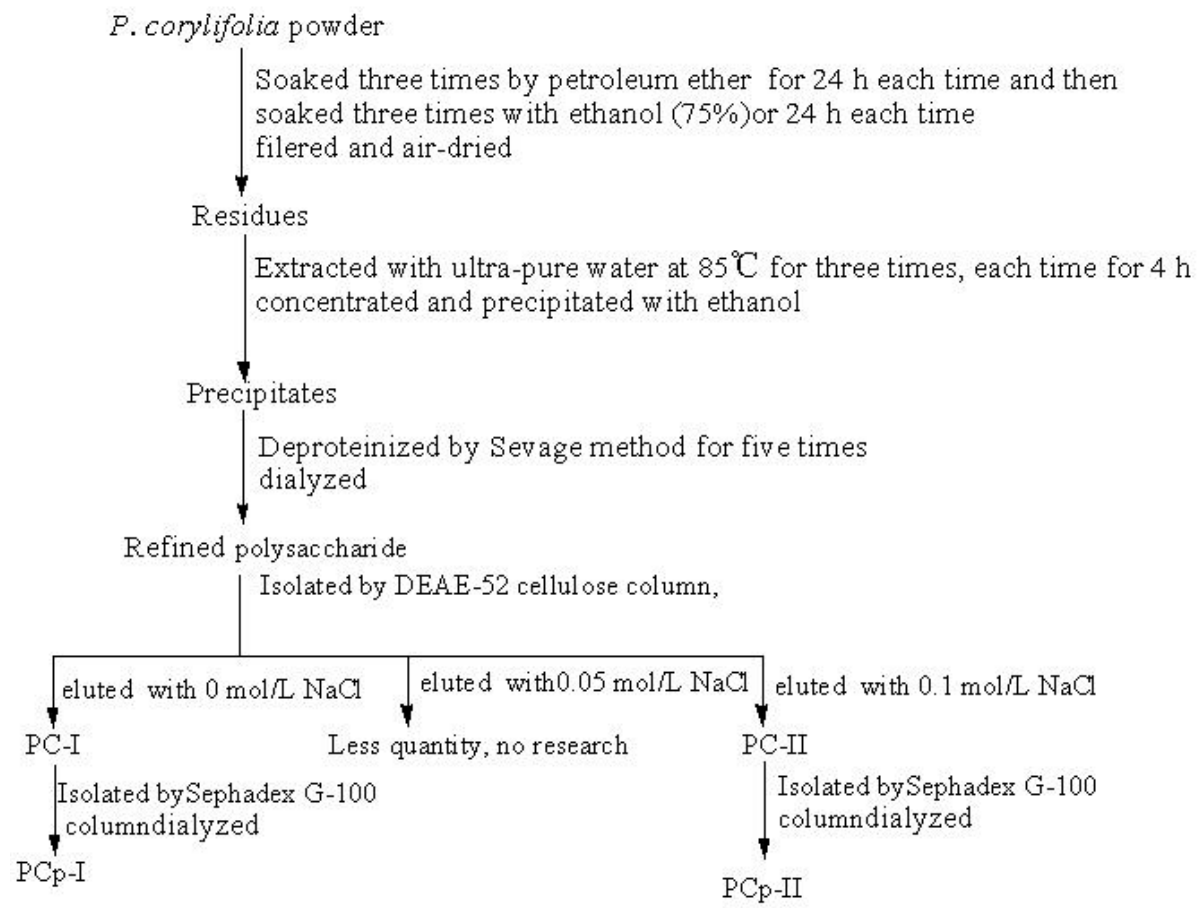

Figure 9. Isolation procedures of polysaccharide from P. corylifolia.

\subsection{General Physical and Chemical Properties}

The total sugar and protein contents of polysaccharides were determined by the phenolsulfuric acid [45] and coomassie brilliant blue G-250 [46] methods, respectively. The solubilities of polysaccharides in hot water, cold water, ethanol, $n$-butanol, acetone, chloroform, and petroleum ether were determined, feilin reagent reaction, ferric trichloride reaction, and iodine-potassium iodide reaction were also carried out [47].

\subsection{Molecular Weight Determination}

The molecular weights of PCP-I and PCp-II were determined by HPSEC) according to Chinese Pharmacopoeia (2015 Edition, General Rules 0514) [48] in Beijing center for physical and chemical analysis.

\subsection{Monosaccharide Composition Analysis}

First, the derivatives (hydrolysis and acetylation) of PCp-I and PCp-II were carried out, and monosaccharide compositions were then analyzed by Gas Chromatography (GC, GC-2010, Shimadzu, Japan) equipped with a HP capillary column $(30 \mathrm{~m} \times 0.35 \mathrm{~mm} \times 0.25 \mu \mathrm{m}$, Aglient Technologies, Inc., PaloAlto, Santa Clara, CA, USA) and a FID detector using the published method [49]. The standard monosaccharides (glucose, xylose, arabinose, rhamnose, mannose, ribose, fructose, and galactose) were derivatized and subjected to GC analysis in the same way. Monosaccharide composition of polysaccharides was identified by comparison with the chromatograms of standard monosaccharides, and the relative molar ratios were calculated by the method of area normalization.

\subsection{Methylation Analysis}

Methylation analysis procedure was conducted according to the method of Ciucanu and Kerek [50] with slight modification [51]. The dried methylated sample was submitted to hydrolysis with trifluoroacetic acid (TFA), reduction with sodium borohydride $\left(\mathrm{NaBH}_{4}\right)$, and acetylation with acetic anhydride to derive partially methylated alditol acetates (PMAA), which were analyzed by capillary GC-MS (Agilent Technologies, USA). A capillary column $(30.0 \times 250.0 \mu \mathrm{m} \times 0.25 \mu \mathrm{m})$ of DB-5 ms, 
held at $110^{\circ} \mathrm{C}$ during injection for $1 \mathrm{~min}$., then programmed at $5{ }^{\circ} \mathrm{C} / \mathrm{min}$. to $180^{\circ} \mathrm{C}$ and held at this temperature for $4 \mathrm{~min}$., at $3{ }^{\circ} \mathrm{C} / \mathrm{min}$. to $210^{\circ} \mathrm{C}$ and held for $8 \mathrm{~min}$. at $5^{\circ} \mathrm{C} / \mathrm{min}$. to $230^{\circ} \mathrm{C}$ and held for $3 \mathrm{~min}$. was used for separation.,

\subsection{FT-IR Spectral Analysis}

The dried polysaccharides (PCp-I and PCp-II) were ground with spectroscopic grade $\mathrm{KBr}$ powder and then pressed into pellets for the analysis. The FT-IR spectrum was recorded in the range of $4000-400 \mathrm{~cm}^{-1}$ on a Thermo Scientific Nicolet iS5 FT-IR spectrophotometer (USA).

\subsection{Nuclear Magnetic Resonance (NMR) Spectroscopy Analysis}

Polysaccharides (PCp-I and PCp-II) were exchanged with deuterium by lyophilizing against deuterium oxide $\left(\mathrm{D}_{2} \mathrm{O}\right)$ twice, and finally dissolved in $\mathrm{D}_{2} \mathrm{O}$ at room temperature for $4 \mathrm{~h}$ before NMR analysis. ${ }^{1} \mathrm{H}$ and ${ }^{13} \mathrm{C}$-NMR spectra were recorded at 400 and $100 \mathrm{MHz}$, respectively, on a Bruker Avanced III $400 \mathrm{MHz}$ NMR spectrometer (Karlsruhe, Germany) at $298 \mathrm{~K}$. The homonuclear ${ }^{1} \mathrm{H}_{-}{ }^{1} \mathrm{H}$ correlation $\left({ }^{1} \mathrm{H}-{ }^{1} \mathrm{H}\right.$ COSY), heteronuclear multi-quantum relationship (HMQC), and heteronuclear multiple-bond correlation (HMBC) experiments were conducted by the standard Bruker pulse sequence.

\subsection{Thermal Stability Analysis}

TGA were obtained from a SDT Q600 instrument (TA Company, Milford, MA, USA), in the temperature range of $30-700{ }^{\circ} \mathrm{C}$ at a heating rate of $5{ }^{\circ} \mathrm{C} / \mathrm{min}$. under the nitrogen atmosphere.

\subsection{Molecular Morphology Observation}

SEM (FEI Quanta 250 FEG, Hillsboro, OR, USA) was employed to observe the morphologies of the PCp-I and PCp-II samples that freeze-dried in the same way. The samples were coated with a thin gold film. The SEM images were observed at a voltage of $20.00 \mathrm{kV}$ under the high vacuum condition.

\subsection{Cell Culture and MTT Assay}

The A549 cells were cultured in RPMI 1640 medium and incubated at $37^{\circ} \mathrm{C}$ with $5 \% \mathrm{CO}_{2}$ under a humidified atmosphere. A549 cells $\left(2 \times 10^{4}\right.$ cells) were seeded in 96-well tissue culture plates and then cultured with PCp-I and II at different concentrations with three repeats for each concentration. After $48 \mathrm{~h}, 10 \mu \mathrm{L}$ MTT was added into each well and maintained for $4 \mathrm{~h}$ at $37^{\circ} \mathrm{C}$. The insoluble violet formazan product was solubilized by the addition of $150 \mu \mathrm{L}$ of DMSO. The absorbance was recorded at $490 \mathrm{~nm}$ by the Envision multimarker microporous plate detection system. Cisplatin was positive control.

\section{Conclusions}

Two novel polysaccharides (PCp-I and PCp-II) were isolated and identified in P. corylifolia L. PCp-I and PCp-II were composed of rhamnose, arabinose, xylose, mannose, glucose, and galactose with different molar ratio, average molecular weight of were $2.721 \times 10^{4}$ and $2.850 \times 10^{4}$, respectively. PCp-I and PCp-II had good thermal stability and different microstructure. Further, PCp-I and PCp-II could inhibit A549 lung cancer cells activity $\left(\mathrm{IC}_{50}=64.84\right.$ and $\left.126.30 \mu \mathrm{M}\right)$ in vitro. Based on methylation and NMR spectroscopy, part structure of PCp-I was proposed, as follows:

$$
\begin{aligned}
& \beta-G l c p-(1 \rightarrow \underset{\downarrow}{2,4)-\alpha-R h a p}-(1 \rightarrow \\
&4)-\alpha-G a l p-(1 \rightarrow 5)-\alpha-A r a f-(1 \rightarrow 4)-\alpha-G a l p-(1 \rightarrow 5)-\alpha-\operatorname{Ara} f-(1]_{\mathrm{n}}
\end{aligned}
$$


Author Contributions: The experiments were conceived by W.Z. and J.W., W.K. and L.C. designed and coordinated the research. Z.Y. performed extraction and isolation of polysaccharides. Z.Y., J.Z. and Q.G. were jointly responsible for the physicochemical properties and structure identification of polysaccharides. H.L. performed thermal stability and microstructure. Z.Y. and W.Z. performed antitumor activity. L.C., W.K., Z.Y. and W.Z. analyzed and compiled the data and co-wrote the manuscript.

Funding: This research was funded by Key research projects of colleges and universities in Henan province (18A360019) and Henan Province Industry-University-Research Cooperation Project (182107000033).

Conflicts of Interest: The authors declare that they have no competing interests.

\section{References}

1. Yang, C.; He, N.; Ling, X.; Ye, M.; Zhang, C.; Shao, W.; Zao, C.; Wang, Z.; Li, Q. The isolation and characterization of polysaccharides from longan pulp. Sep. Purif. Technol. 2008, 63, 226-230. [CrossRef]

2. Basu, S.; Ghosh, M.; Bhunia, R.K.; Ganguly, J.; Banik, B.K. Polysaccharides from Dolichos biflorus Linn and Trachyspermum ammi Linn seeds: Isolation, characterization and remarkable antimicrobial activity. Chem. Cent. J. 2017, 11, 118. [CrossRef] [PubMed]

3. Lin, X.; Ji, X.; Wang, M.; Yin, S.; Peng, Q. An alkali-extracted polysaccharide from Zizyphus jujuba cv. Muzao: Structural characterizations and antioxidant activities. Int. J. Biol. Macromol. 2019, 136, 607-615. [CrossRef] [PubMed]

4. Wang, J.Y.; Wang, H.L.; Zhang, H.L.; Liu, Z.H.; Ma, C.Y.; Kang, W.Y. Immunomodulation of ADPs-1a and ADPs-3a on RAW264.7 cells through NF-кB/MAPK signaling pathway. Int. J. Biol. Macromol. 2019, 132, 1024-1030. [CrossRef]

5. Han, K.; Jin, C.; Chen, H.J.; Wang, P.P.; Yu, M.; Ding, K. Structural characterization and anti-A549 lung cancer cells bioactivity of a polysaccharide from Houttuynia cordata. Int. J. Biol. Macromol. 2018, 120, 288-296. [CrossRef]

6. Xin, X.; Zheng, K.W.; Niu, Y.Y.; Song, M.M.; Kang, W.Y. Effect of Flammulina velutipes (golden needle mushroom, eno-kitake) polysaccharides on constipation. Open Chem. 2018, 16, 155-162. [CrossRef]

7. Wang, J.M.; Lian, P.L.; Yu, Q.; Wei, J.F.; Kang, W.Y. Antithrombotic mechanism of polysaccharides in Blackberry (Rubus spp.) seeds. Food Nutr. Res 2017, 61, 1379862. [CrossRef]

8. Chinese Pharmacopoeia Committee. Pharmacopoeia of the People's Republic of China; China Medical Science and Technology Press: Beijing, China, 2015; Part I; pp. 181-188.

9. Kim, Y.J.; Lim, H.S.; Lee, J.; Jeong, S.J. Quantitative Analysis of Psoralea corylifolia Linne and its Neuroprotective and Anti-Neuroinflammatory Effects in HT22 Hippocampal Cells and BV-2 Microglia. Molecules 2016, 21, 1076. [CrossRef]

10. Lin, X.; Li, B.B.; Zhang, L.; Li, H.Z.; Meng, X.; Jiang, Y.Y.; Lee, H.S.; Cui, L. Four new compounds isolated from Psoralea corylifolia and their diacylglycerol acyltransferase (DGAT) inhibitory activity. Fitoterapia 2018, 128, 130-134. [CrossRef]

11. Huang, Y.; Liu, X.; Wu, Y.; Li, Y.; Guo, F. Meroterpenes from Psoralea corylifolia against Pyricularia oryzae. Planta Med. 2014, 80, 1298-1303. [CrossRef]

12. Zheng, C.X.; Li, X.S.; Su, P.J.; Huang, X.Y.; Fu, G.M.; Li, Y.; Huang, S.Y. A study of full-thickness articular cartilage defects repaired by Psoraleae polysaccharide in rabbits. Chin. J. Joint Surg. 2011, 5, 201-207.

13. Yang, G.; Li, F.S.; Liu, H. Effect of Polysaccharide from Psoralea corylifolia L on Excited State Immune Function in Mice. J. Chin. Med. Mater. 2004, 27, 42-44.

14. Li, F.S.; Yang, G.; Xu, H.G.; Li, M.Y.; Liu, H. Study on Immunity Activity of Polysaccharide Extracted from Psoralea corylifolia L. China Pharm. 2008, 11, 140-142.

15. Latha, P.G.; Evans, D.A.; Panikkar, K.R.; Jayavardhanan, K.K. Immunomodulatory and antiumour properties of Psoralea corylifolia. Fitoterapia 2000, 71, 223-231. [CrossRef]

16. Whelan, L.C.; Ryan, M.F. Ethanolic extracts of euphorbia and other ethnotanical species as inhibitors of human tumour cell growth. Phytomedicine 2003, 10, 53-58. [CrossRef]

17. Song, Y.F.; Wang, Q.K.; Wang, Q.J.; He, Y.H.; Ren, D.D.; Liu, S.; Wu, L. Structural characterization and antitumor effects of fucoidans from brown algae Kjellmaniella crassifolia farmed in northern China. Int. J. Biol. Macromol. 2018, 119, 125-133. [CrossRef] [PubMed] 
18. Cantu-Jungles, T.M.; Iacomini, M.; Cipriani, T.R.; Cordeiro, L.M.C. Extraction and characterization of pectins from primary cell walls of edible açaí (Euterpe oleraceae) berries, fruits of a monocotyledon palm. Carbohydr. Polym. 2017, 158, 37-43. [CrossRef] [PubMed]

19. Hokputsa, S.; Harding, S.E.; Inngjerdingen, K.; Jumel, K.; Michaelsen, T.E.; Heinze, T.; Koschellad, A.; Paulsen, B.S. Bioactive polysaccharides from the stems of the thai medicinal plant Acanthus ebracteatus: Their chemical and physical features. Carbohydr. Res. 2004, 339, 753-762. [CrossRef]

20. Jiang, J.Y.; Kong, F.S.; Li, N.; Zhang, D.; Yan, C.; Lv, H. Purification, structural characterization and in vitro antioxidant activity of a novel polysaccharide from Boshuzhi. Carbohydr. Polym. 2016, 147, 365-371. [CrossRef]

21. Hu, Z.Y.; Zhou, H.L.; Li, Y.P.; Wu, M.F.; Yu, M.; Sun, X.S. Optimized purification process of polysaccharides from Carex meyeriana Kunth by macroporous resin, its characterization and immunomodulatory activity. Int. J. Biol. Macromol. 2019, 132, 76-86. [CrossRef]

22. Zhang, H.; Nie, S.P.; Cui, S.W.; Xu, M.; Ding, H.H.; Xie, M.Y. Characterization of a bioactive polysaccharide from Ganoderma atrum: Re-elucidation of the fine structure. Carbohydr. Polym. 2017, 158, 58-67. [CrossRef] [PubMed]

23. Jiang, B.; Peng, Q.F.; Shen, Z.G.; Möller, M.; Pi, E.X.; Lu, H.F. Taxonomic treatments of Camellia (Theaceae) species with secretory structures based on integrated leaf characters. Plant Syst. Evol. 2010, 290, 1-20. [CrossRef]

24. Ma, G.; Yang, W.; Mariga, A.M.; Fang, Y.; Ma, N.; Pei, F.; Hu, Q.H. Purification: Characterization and antitumor activity of polysaccharides from Pleurotus eryngii residue. Carbohydr. Polym. 2014, 114, 297-305. [CrossRef] [PubMed]

25. Yang, B.; Wang, J.; Zhao, M.; Liu, Y.; Wang, W.; Jiang, Y. Identification of Polysaccharides from pericarp tissues of litchi (Litchi chinensis Sonn.) fruit in relation to their antioxidant activities. Carbohydr. Res. 2006, 341, 634-638. [CrossRef]

26. Manna, D.K.; Maity, P.; Nandi, A.K.; Pattanayak, M.; Panda, B.C.; Mandal, A.K.; Tripathy, S.; Acharya, K.; Sahoo, A.K.; Gupta, N.; et al. Structural elucidation and immunostimulating property of a novel polysaccharide extracted from an edible mushroom Lentinus fusipes. Carbohydr. Polym. 2017, 157, 1657-1665. [CrossRef]

27. Wang, L.L.; Zhang, X.F.; Niu, Y.Y.; Ahmed, A.F.; Wang, J.M.; Kang, W.Y. Anticoagulant activity of two novel polysaccharides from flowers of Apocynum venetum L. Int. J. Biol. Macromol. 2019, 124, 1230-1237. [CrossRef]

28. Polle, A.Y.; Ovodova, R.G.; Shashkov, A.S.; Ovodov, Y.S. Some structural features of pectic polysaccharide from tansy, Tanacetum vulgare L. Carbohydr. Polym. 2002, 49, 337-344. [CrossRef]

29. Cardoso, S.M.; Ferreira, J.A.; Mafra, I.; Silva, A.M.S.; Coimbra, M.A. Structural ripening-related changes of the Arabian-rich pectic polysaccharides from olive pulp cell walls. J. Agric. Food Chem. 2007, 55, 7124-7130. [CrossRef]

30. Agrawal, P.K. NMR Spectroscopy in the structural elucidation of oligosac-charides and glycosides. Phytochemistry 1992, 31, 3307-3330. [CrossRef]

31. Bushneva, O.A.; Ovodova, R.G.; Shashkov, A.S.; Ovodov, Y.S. Structural studies on hairy region of pectic polysaccharide from campion Silene vulgaris (Oberna behen). Carbohydr. Polym. 2002, 49, 471-478. [CrossRef]

32. Kang, J.; Cui, S.W.; Phillips, G.O.; Chen, J.; Guo, Q.B.; Wang, Q. New studies on gum ghatti (Anogeissus latifolia) Part III: Structure characterization of a globular polysaccharide fraction by 1D, 2D NMR spectroscopy and methylation analysis. Food Hydrocoll. 2011, 25, 1999-2007. [CrossRef]

33. Polle, A.Y.; Ovodova, R.G.; Chizhov, A.O.; Shashkov, A.S.; Ovodov, Y.S. Structure of Tanacetan, a Pectic Polysaccharide from Tansy Tanacetum vulgare L. Biochemistry 2002, 67, 1371-1376. (In Moscow) [PubMed]

34. Corsaro, M.M.; Evidente, A.; Lanzetta, R.; Lavermicocca, P. Structural determination of the phytotoxic mannan exopolysaccharide from Pseudomonas syringae pv. Ciccaronei. Carbohydr. Res. 2001, 330, 271-277. [CrossRef]

35. Yin, J.Y.; Chan, B.C.L.; Yu, H.; Lau, I.Y.K.; Han, X.Q.; Cheng, S.W.; Wong, C.K.; Lau, C.B.S.; Xie, M.Y.; Fung, K.P.; et al. Separation, structure characterization, conformation and immunomodulating effect of a hyperbranched heteroglycan from Radix Astragali. Carbohydr. Polym. 2012, 87, 667-675. [CrossRef] 
36. Vendruscolo, C.W.; Ferrero, C.; Pineda, E.A.; Silveira, J.L.; Freitas, R.A.; Jiménez-Castellanos, M.R.; Bresolin, T.M. Physicochemical and mechanical characterization of galactomannan from Mimosa scabrella: Effect of drying method. Carbohydr. Polym. 2009, 76, 86-93. [CrossRef]

37. Wang, M.X.; Gao, Y.; Xu, D.D.; Gao, Q.P. A polysaccharide from cultured mycelium of Hericium erinaceus and its anti-chronic atrophic gastritis activity. Int. J. Biol. Macromol. 2015, 81, 656-661. [CrossRef]

38. Trigui, I.; Yaich, H.; Sila, A.; Cheikhrouhou, S.; Bougatef, A.; Blecker, C.; Attia, H.; Ayadi, M.A. Physicochemical properties of water-soluble polysaccharides from black cumin seeds. Int. J. Biol. Macromol. 2018, 117, 937-946. [CrossRef]

39. Martin, G.S. Cell signaling and cancer. Cancer Cell 2003, 4, 167-174. [CrossRef]

40. Qi, C.C.; Zhu, H.T.; Li, S.H.; Yuan, F.; Wang, S. Evaluation of efficacy and safety for lentinan in the control of the malignant pleural effusions via intrapleural injection. Am. J. Med. Sci 2019, in press.

41. Wu, W.B.; Zhu, W. Clinical study on Ginseng Polysacchride Injection combined with epirubicin in treatment of breast cancer. Drugs Clin. 2018, 33, 2036-2039.

42. Yin, Z.H.; Zhang, W.; Zhang, J.J.; Kang, W.Y. Isolation, purifcation, structural analysis and coagulatory activity of water-soluble polysaccharides from Ligustrum lucidum Ait fowers. Chem. Cent. J. 2017, 11, 98. [CrossRef] [PubMed]

43. Xie, J.H.; Xie, M.Y.; Nie, S.P.; Shen, M.Y.; Wang, Y.X.; Li, C. Isolation, chemical composition and antioxidant activities of a water-soluble polysaccharide from Cyclocarya paliurus (Batal.) Iljinskaja. Food Chem. 2010, 119, 1626-1632. [CrossRef]

44. Tang, W.; Lin, L.H.; Xie, J.H.; Wang, Z.J.; Wang, H.; Dong, Y.J.; Shen, M.Y.; Xie, M.Y. Effect of ultrasonic treatment on the physicochemical properties and antioxidant activities of polysaccharide from Cyclocarya paliurus. Carbohydr. Polym. 2016, 151, 305-312. [CrossRef] [PubMed]

45. Dubois, M.; Gilles, K.A.; Hamilton, J.K.; Rebers, P.A.; Smith, F. Colorimetric method for Determination of sugars and related substances. Anal. Biochem. 1956, 28, 350-356. [CrossRef]

46. Bradford, M.M. A rapid and sensitive method for the quantitation of microgram quantities of protein utilizing the principle of protein dye binding. Anal. Biochem. 1976, 72, 248-254. [CrossRef]

47. Zhao, H.H. Study on The Extraction, Purification and Antioxidant Activities in vitro of Polysaccharides from Okra. Master's Thesis, Zhengzhou University, Zhengzhou, China, 2012.

48. Chinese Pharmacopoeia Committee. Pharmacopoeia of the People's Republic of China; China Medical Science and Technology Press: Beijing, China, 2015; Part IV; pp. 62-63.

49. Wang, J.M.; Lian, P.L.; Yu, Q.; Wei, J.F.; Kang, W.Y. Purification, characterization and procoagulant activity of polysaccharides from Angelica dahurice roots. Chem. Cent. J. 2017, 11, 17. [CrossRef]

50. Ciucanu, I.; Kerek, F. A simple and rapid method for the permethylation of carbohydrates. Carbohydr. Res. 1984, 131, 209-217. [CrossRef]

51. Guo, Q.B.; Cui, S.W.; Kang, J.H.; Ding, H.; Wang, Q.; Wang, C. Non-starch polysaccharides from American ginseng: Physicochemical investigation and structural characterization. Food Hydrocoll. 2015, 44, 320-327. [CrossRef]

Sample Availability: Samples of the compounds PCp-I and PCp-II are available from the authors.

(C) 2019 by the authors. Licensee MDPI, Basel, Switzerland. This article is an open access article distributed under the terms and conditions of the Creative Commons Attribution (CC BY) license (http://creativecommons.org/licenses/by/4.0/). 